\title{
¿Una nueva doctrina para el sacramento del matrimonio?
}

\author{
ALAIN MATTHEEUWS, S.J. \\ Faculté de Théologie de la Compagnie de Jésus (Bruxelles, Bélgique) \\ alainmattheeuws@jesuites.be
}

\begin{abstract}
Resumen
En los inicios del tercer milenio, ¿abre la humanidad la puerta a una nueva era: la del vacío, la de un mundo que ya no canta? ¿El hombre estará condenado a permanecer como un lobo para el hombre? ¿La relación hombre-mujer no sería más bien una dialéctica de dominio y servidumbre? En este artículo nos proponemos sintetizar rápidamente las dos primeras etapas de las doctrinas clásicas sobre el matrimonio y luego, explicitar más extensamente lo que nos parece ser una «nueva doctrina», la de los «dones del matrimonio». Finalizaremos mostrando la originalidad y las implicancias de esta novedad. A través de los riesgos históricos del desarrollo de estas doctrinas quisiéramos manifestar la coherencia propia de cada una de ellas, subrayar también una cierta continuidad histórica y teológica a la vez, particularmente en el paso de la una a la otra. Las tres doctrinas del matrimonio: la de los «bienes», la de los «fines» y la de los «dones» son tres doctrinas que están en continuidad y cada una de ellas trata de descubrir el misterio del sacramento del matrimonio.
\end{abstract}

Palabras claves: matrimonio, sacramento, misterio, amor, acto conyugal.

\section{A new doctrine for the sacrament of marriage?}

\begin{abstract}
At the beginning of the third millennium, does humanity open the door to a new era: the era of emptiness, the era of a world that no longer sings? Is man doomed to remain a wolf to man? Is the relationship between man and woman rather a dialectic of domination and servitude? In this article we propose to quickly synthesize the first two stages of the classical doctrines on marriage and then explain more fully what seems to be a «new doctrine» of the "rigts of marriage». We finish explaining the originality and the implications of this development. Through the historical risks of the developing of these doctrines we would like to express the coherence of each of these, also to underline some historical and theological continuity while, particularly in the

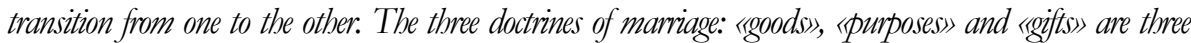
doctrines that are continuous and each tries to uncover the mystery of the sacrament of marriage.
\end{abstract}

Key words: marriage, sacrament, mystery, love, conjugal act.

Jesuita (1973), sacerdote (1985), Biólogo de formación, licenciado en Teología Moral en la Pontificia Universidad Gregoriana y Doctor en Teología en el Instituto Católico de Toulouse. Actualmente es Profesor ordinario en la Facultad de Teología de los jesuitas (I.E.T) de Bruselas. Publicaciones recientes: "L'amour de Dieu ne meurt jamais. La sainteté des divorcés remariés dans l'Eglise" (2014), y "Pourquoi l'Eglise s'intéresse-t-elle à la famille?" (2014).

Este artículo fue traducido del original francés por Guillermo Calderón Núñez con la debida autorización del autor. 


\section{Introducción}

El P. Martelet, renombrado jesuita francés, escribía en 1969 que «alrededor del matrimonio y del amor se desarrolla uno de los combates más decisivos de nuestro tiempo. De su resultado dependen el hombre y la sociedad de mañana» (Martelet, 1969: 153). En efecto, en el matrimonio y el amor todas las penurias humanas atraviesan al corazón del hombre: incomprensión, violencia, rupturas, carencias, necesidades, fracasos. Los hijos no están ausentes de estos dolores. Esta afirmación encuentra confirmación en la evolución de nuestras sociedades, en la era de la globalización. Las intervenciones magisteriales del último pontificado, las reflexiones teológicas y las problemáticas pastorales relacionadas con el sacramento del matrimonio despiertan todavía más preguntas fundamentales. De un principio, lo confesamos: los grandes debates de la Iglesia sobre el matrimonio, la interpretación de la doctrina sobre los fines del matrimonio, las preguntas y rebeliones de los hombres y mujeres de nuestro tiempo pertenecen al paisaje de este artículo.

En los inicios del tercer milenio, cabre la humanidad la puerta a una nueva era: la del vacío, la de un mundo que ya no canta? ¿El hombre estará condenado a permanecer como un lobo para el hombre? ¿La relación hombre-mujer no sería más bien una dialéctica de dominio y servidumbre?

La paradoja que defendemos es la siguiente: afirmamos que estas penurias no forman sino la trama fundamental de nuestro universo. El amor es más fuerte que toda muerte. Puesto que Dios es amor y que se entrega, el hombre y la mujer son también capaces de amarse en verdad. El don es el verdadero nombre del ser, «perfora el corazón del hombre y encontrarás un sol» dice un antiguo proverbio egipcio muy estimado por Sor Emmanuelle ${ }^{1}$. El corazón del hombre es poder de don y vida.

El tiempo hace su obra y parece confirmar la importancia de una teología del don subyacente a numerosos desarrollos sacramentales, eclesiológicos y morales. En este artículo nos proponemos, sintetizar rápidamente las dos primeras etapas de las doctrinas clásicas sobre el matrimonio y luego, explicitar más extensamente lo que nos parece ser una «nueva doctrina», la de los «dones del matrimonio». Finalizaremos explicitando la originalidad y las implicancias de esta novedad. A través de los riesgos históricos del desarrollo de estas doctrinas quisiéramos manifes-

\footnotetext{
1 Sor Emmanuelle, nacida Madeleine Cinquin, (1908-2008) fue una maestra, escritora y religiosa franco-belga conocida por su trabajo con personas marginadas y por sus escritos sobre el cristianismo y la Doctrina Social de la Iglesia. [Nota del Traductor].
} 
tar la coherencia propia de cada una de estas doctrinas, subrayar también una cierta continuidad histórica y teológica a la vez, particularmente en el paso de la una a la otra. Las tres doctrinas del matrimonio: la de los «bienes», la de los «fines» y la de los «dones» son tres doctrinas que están en continuidad y cada una de ellas trata de descubrir el misterio del sacramento del matrimonio.

\section{Las sucesivas doctrinas}

La teología del matrimonio no está exenta de ásperos debates que todavía hoy resuenan: la institución del sacramento por Cristo, las cuestiones relativas a los ministros y el rol del sacerdote, la importancia del contrato entre los esposos, el rol del acto conyugal. Todos ellos, temas siempre actuales. Conceptos como «alteridad», «autonomía», «libertad»se experimentan en la carne del hombre y de la mujer, en el fruto de sus entrañas. Además, el sacramento del matrimonio como estado de vida involucra a muchos fieles. La manera de vivir esta vocación expresa y verifica a menudo la calidad de la fe vivida. Es uno de los lugares privilegiados donde la fe es vida y donde el dogma es moral.

En la historia de la Iglesia latina podemos distinguir dos etapas en lo relacionado a la constitución de la doctrina católica del matrimonio: el aporte agustiniano y la reflexión tomista.

\subsection{La doctrina agustiniana de los «bienes» del matrimonio}

Esta doctrina está sacada de la reflexión y de la acción pastoral de San Agustín. Se trata, para él, de afirmar la bondad intrínseca del matrimonio frente a una controversia de esta realidad humana y eclesial. La palabra «bien», tanto en singular como en plural, hace referencia a la bondad del matrimonio creado por Dios.

San Agustín retoma, por supuesto, la tradición de la Iglesia y usa el aporte de sus predecesores, pero él agrega algo verdaderamente nuevo y personal. Lo hace a través de diversas obras que lo hacen merecedor del sobrenombre de Doctor del matrimonio. Su reflexión representa una etapa importante en la historia de la Iglesia. Debemos darnos cuenta que desde 430 d.C., fecha de la muerte de San Agustín, hasta 1930, fecha de la Encíclica Casti connubi de Pío XII, la doctrina agustiniana, como referencia principal, será enseñada, pensada y vivida al interior de la Iglesia de manera continua.

La investigación teológica y el combate mismo de Agustín no están centrados en la finalidad del matrimonio sino en su valor ético. Su reflexión depende de un contexto cultural y eclesial donde el maniqueísmo es 
el adversario principal ${ }^{2}$. En este contexto polémico, San Agustín se esfuerza en defender la bondad moral del matrimonio. Los maniqueos consideraban la procreación, por ejemplo, como obra del dios malo del Antiguo Testamento. Rehusaban el matrimonio a los perfectos y no lo autorizaban para los otros adeptos sino bajo la condición de hacerlo infecundo. De ahí la insistencia de Agustín sobre la procreación en su tratado sobre el bien conyugal. Este contexto explica igualmente su cuidado de promover la bondad del matrimonio ante el pueblo cristiano. Esta bondad del matrimonio se expresa en lo que se ha llamado la Trilogía Agustiniana de los «bienes» del matrimonio. Ésta se enuncia como sigue: Proles-Fides-Sacramentum.

La Proles designa precisamente la procreación y educación de los hijos. Es el objetivo aparentemente más evidente del matrimonio, sin que así se definiese estrictamente el matrimonio puesto que los hijos pueden nacer fuera del matrimonio y pueden haber uniones estériles.

La Fides es la fidelidad que traduce el compromiso de no tener nunca relaciones carnales sino con el cónyuge. Sin embargo, este rechazo del adulterio no es solo el aspecto negativo de un valor: la fidelidad. Esta está ligada a la importancia concedida a la palabra empeñada y a sus significados. La verdad está en el compromiso prometido, la palabra verdad ya era bien conocida en esa época. Cuando Agustín habla de Fides, se trata de que, lo que cuenta, es un compromiso y una promesa recíproca, y el matrimonio-sacramento confirmará su carácter irrevocable.

Finalmente, Agustín describe el Bien llamado Sacramentum. No se trata, primeramente, del sentido «medieval-moderno» del término «sacramento», sino del sentido de lazo sagrado e indisoluble. El Sacramentum en el cuadro de la cultura latina de Agustín, evoca en primer lugar, el juramento que se hace en ciertas circunstancias. No presenta principalmente las características psicológicas o sacramentales de la fidelidad sino más bien el aspecto jurídico del rechazo al divorcio y de las segundas nupcias. El Sacramentum es un bien porque no se puede eludir o terminar la promesa sagrada que liga al hombre y a la mujer. Lo que ha sido prometido y dado en el matrimonio debe ser respetado. Es un bien porque el esposo y la esposa separados no pueden volver a casarse con otro cónyuge, incluso con la intención de tener hijos. El contenido del término agustiniano Sacramentum debe ser enriquecido en la toma de conciencia posterior del septenario, pues el matrimonio es uno de los siete sacramentos. Esta reflexión será más amplia a partir del siglo XII. Después del Conci-

2 El maniqueísmo es una doctrina elaborada por Mani, de origen y esencia pagana. Una metafísica dualista (mal y bien al mismo nivel, un principio bueno y un principio malo) que desemboca en una ascética pesimista en relación a la carne. 
lio Vaticano II, tendremos que situar la realidad sacramental en el horizonte del sacramento que es la Iglesia. Existe pues, a lo largo de la historia de la Iglesia un contexto teológico más profundo de la palabra Sacramentum. No se trata simplemente de un «juramento» ${ }^{3}$. Estos son los que todavía son llamados «bienes» agustinianos y representan los tres pilares de su doctrina.

Subrayemos ahora que la palabra «bien» posee un significado distinto al de la palabra «fin», pues si todo «fin» del matrimonio es un «bien» que se alcanza, todo «bien» no es necesariamente un «fin». De alguna manera solo la Bonum Prolis, el «bien» de la procreación del hijo puede ser tomado directamente como un «fin». Las dos problemáticas son diferentes y tanto las perspectivas como las realidades definidas no coinciden totalmente. Esta diferencia no es solo histórica sino también teológica. La problemática de los «bienes» implica que se ubica en una perspectiva de valor, es decir, se busca justificar la bondad del matrimonio. Mientras que la de los «fines» se dedica a comprender la naturaleza y el sentido del matrimonio. Puesto que el valor o la bondad de una cosa es lo que nos mueve subjetivamente a la acción, es lo que nos hace actuar, hace que San Agustín llegue a hablar de estos bienes del matrimonio en términos de causa y finalidad, al menos subjetiva. Esta reflexión indica que las dos doctrinas que aquí estudiamos están ligadas una a otra aunque haya una distinción.

\subsection{La doctrina tomista de los «fines»}

Algunos predecesores de Santo Tomás prepararon el terreno para una nueva doctrina. Cito los nombres: San Isidoro de Sevilla, San Buenaventura, San Hugo de San-Víctor. Esta doctrina de la finalidad se expandió a la vez, en la reflexión filosófica y escriturística de Santo Tomás. Está fundada en la definición de la ley natural que pone al hombre en el marco del conjunto genérico de los animales, pero que destaca en la palabra «naturaleza» el aspecto de razón y de especificidad del hombre. Utilizando la palabra «naturaleza humana» Santo Tomás pone ahí todo lo que implica nuestra apertura Dios, nuestro deseo de conocer a Dios, nuestra naturaleza social que nos empuja a mantener relaciones comunes, relaciones de intercambio, relaciones con los que están con nosotros en la sociedad.

En este marco, Santo Tomás va a desarrollar una descripción de la relación conyugal del matrimonio utilizando la ley natural y manifestando

3 Me salto los otros rasgos agustinianos del matrimonio. Véase, Mattheeuws, 1989:
34-38. 
el «por qué» de esta relación entre el hombre y la mujer. Tomás «ordena» pues los fines del matrimonio según sus propias categorías aristotélicas, distingue los «fines» primarios y secundarios del contrato conyugal. El marco es, al mismo tiempo, especulativo y jurídico. ¿Qué es esta finalidad? Se trata de una finalidad en correspondencia con el ser del hombre, con su naturaleza originada y participante del mundo animal, pero igualmente especificada en todo su ser por la razón. Tomás distingue entre «fines» accidentales (que pueden no ser explicitados ni existir antes del matrimonio) y fines esenciales (que pertenecen propiamente) del matrimonio. Estos últimos se dividen en dos tipos: fines primarios y secundarios.

$\mathrm{El}$ «fin» primario es la procreación y educación de los hijos y los «fines» secundarios son, primero, la ayuda mutua o la conversación entre el hombre y la mujer y, luego, el remedium concupiscenciae o remedio de la concupiscencia ${ }^{4}$. No se trata de un apaciguamiento de la concupiscencia humana sino de la sanación del ser herido del hombre.

En la terminología utilizada, se habla de «fines» esenciales que corresponden a la esencia del hombre, a su naturaleza. Se les distingue directamente de los «fines» accidentales, es decir, «fines» que corresponden al azar o a las finalidades indefinidas. Que un hombre y una mujer sean complementarios en sus cualidades no pertenece a la esencia de lo que ellos son. Esta complementariedad puede ser una motivación suplementaria para casarse, unirse para toda la vida, pero no es «esencial» a su amor, es más bien un accidente. Estas cualidades, en primer lugar, no están ligadas a su ser natural sino a la manera que se conocieron. Los «fines» esenciales tocan, al contrario, el ser profundo del hombre.

Los «fines» esenciales llamados secundarios no deben llevar a engaño. Su carácter «primario-secundario» no los exime de su «importancia esencial». Muchos autores, al parecer, se han equivocado acerca de este punto y han interpretado mal la doctrina tomista. Diciendo «secundario», han creído que estos «fines» podían ser utilizados e instrumentalizados

$4 \quad \mathrm{El}$ «remedio» indica que el amor humano debe y es salvado por Cristo en el sacramento, como toda realidad humana, ni más ni menos. El «remedio» no solo indica una ayuda o una suerte de «válvula de seguridad» a posibles situaciones desordenadas (por ej. casarse para sanar la homosexualidad). Este «remedio» apela a la necesidad, para el hombre herido por el pecado original y por sus pecados personales (o del otro) de articular en la unidad del amor y el gesto sexual, el eros y la caridad. El «remedio» es una instancia de integración entre espiritualidad y corporeidad, entre ternura y espiritualidad, comunión de corazones y comunión de cuerpos. El sacramento del matrimonio ofrece un lugar para esta «instancia». Es un símbolo, un acto de sanación que incluye la promesa que lo garantiza.

5 Por ejemplo, dos médicos con la posibilidad de abrir una consulta común, alianzas principescas, ser símbolo de la unidad de un país. 
respecto del «fin primario» de modo que la unión o la ayuda mutua estaban relacionadas únicamente a la procreación y educación de los hijos. Se unían para tener hijos o a la inversa. De hecho los dos «fines» esenciales son dos «fines» que valen por sí mismos. Santo Tomás ha retomado la doctrina de los «bienes» de San Agustín y los ha reinstalado en una reflexión general donde, teniendo como fondo el marco de la ley natural, puede manifestar la finalidad teologal y la variedad de las causas. Señalemos, siguiendo a los especialistas, que santo Tomás no ha podido retomar toda la doctrina de los «bienes» en su sistema, hay una parte de aporía o de trabajo no terminado cuando él muere. Esta dificultad permanecerá pendiente por siglos hasta la aparición de nuevos elementos y la aceleración de la historia de la doctrina del matrimonio en el siglo XX. Esta reflexión tomista, que no reniega el aporte agustiniano, ha sido clásica en la Iglesia hasta el Concilio Vaticano II.

\section{Integración de las doctrinas teológicas en el Magisterio}

Recordemos que el Magisterio y la Tradición no coinciden en absoluto. La Tradición desborda siempre al Magisterio. «Creemos, en efecto, que el Espíritu Santo ha sido dado a la Iglesia entera para que la redescubra cada vez más a lo largo de los siglos, en comunión con sus pastores, la plenitud de la Revelación que le ha sido hecha, plenitud que implica no solo lo que ella cree, sino también lo que ella espera y lo que ella practica en su vida de caridad. La Tradición viva de la Iglesia resulta de su mediación incesante, particularmente en la liturgia, de la Palabra de Dios que le fue dirigida y que está consignada en la Sagrada Escritura. De esta oración derivan su comprensión de la Revelación divina, su puesta en práctica de las exigencias concretas de la caridad y su predicación misma. Esta oración, por otra parte, no es comprensible sin referencia a la Palabra de Dios fielmente predicada y auténticamente interpretada. Así, Tradición viva y Magisterio son realidades inseparables que se envuelven una a otra. Pueden ser comprendidas la una a partir de la otra» (Hennaux, 1989). Dei Verbum lo recuerda de manera decisiva en el $\mathrm{N}^{\circ} 10$.

La integración de las dos doctrinas en el Magisterio está manifestada sobre puntos precisos, a la vez, en el Derecho canónico y a través de las intervenciones personales de varios Papas. Pío XI, en 1930, testimoniaba acerca de la perennidad de la doctrina de los «bienes» integrando igualmente la referencia a los «fines» del matrimonio. La encíclica Casti connubi, pequeño tratado sobre el matrimonio, está centrada y marcada por la consideración de los bienes del matrimonio. La finalidad es, también, mencionada explícitamente: «Hay, pues, tanto en el mismo matrimonio como en el uso del derecho matrimonial, fines secundarios -verbigracia, 
el auxilio mutuo, el fomento del amor recíproco y la sedación de la concupiscencia- cuya consecución en manera alguna está vedada a los esposos, siempre que quede a salvo la naturaleza intrínseca del acto y, por ende, su subordinación al fin primario» (Pío XI, Casti connubi, 22).

Esta doctrina fue integrada también en el magisterio de Pío XII y ya antes en el Código de Derecho Canónico de 1917 (CIC, c.1013, n.1, 1917). Las reflexiones de Pío XII sobre la doctrina de los «fines» surgen en un contexto conflictivo para denunciar dos tendencias que serían, según Pío XII, funestas: la primera tendencia consistiría en sobrevalorar el «fin» primario del matrimonio al punto de negar la existencia de los otros fines, los secundarios y la segunda tendencia, buscaría, al contrario, desligar el «fin» secundario de una subordinación al «fin» primario al punto de considerarlo como «fin» principal. Las intervenciones de Pío XII están ahí para recordarnos que existe un equilibrio, a saber, que la doctrina es siempre válida, que es importante y que expresa la reflexión de la Iglesia en ese momento. El Código de Derecho canónico integraba en aquella época el concepto «jerárquico» entre ambos «fines». Existe un orden entre el «fin» primario y el secundario, orden del cual no se mencionaba la «cualidad» en el código: ¿ंorden de superioridad?, ¿ंorden cronológico?, ¿orden ontológico? El código del 1917 no decía nada al respecto.

\subsection{Período pre conciliar: dificultades y objeciones}

Numerosos signos de oposición a estas doctrinas se manifestaron con menos fuerza durante el periodo preconciliar. Nos referimos sobre todo a las críticas a las finalidades hechas por H. Doms en 1937 y la toma de conciencia acerca de la importancia subjetiva del amor en los esposos. ¿Cuál debería ser el lugar del amor en la reflexión sobre el sacramento del matrimonio? ¿Cómo reconocer y valorar la gracia propia de los esposos: la santidad de su estado y su misión en la Iglesia? Cómo se enuncian estas dificultades y cuál es su problemática.

Primeramente, numerosos autores no quieren considerar la procreación y la educación de los hijos como «fin primario» comprendido como objetivo principal o exclusivo y, por otra parte, describen otros «fines» dándoles un status propio. En suma, quieren oponer dialécticamente los dos tipos de «fines». Es necesario elegir para no conservar sino una sola finalidad, vista ésta a menudo a través de una percepción puramente subjetiva. Se termina eligiendo un solo «fin» y se deja los otros «fines» al servicio de aquel. Se olvida así que para Santo Tomás desde el principio, los dos «fines» eran vistos como esenciales y considerados siempre como unidad. Situación compleja que suscita numerosas controversias. Diver- 
sos autores presentan ensayos de adaptación y de reactualización de la doctrina de los fines. Ellos no convencen totalmente.

Las doctrinas de los «bienes»y de los «fines» son así expuestas a profundas dificultades de interpretación. Si se piensa en términos estrictos de finalidad, en un mundo donde domina la epistemología científica y técnica, se corre el riesgo de reducir toda finalidad, especialmente la procreación, a un fin social (los esposos deben unirse para procrear) o, peor todavía, a un fin biológico, en lugar de ver en la procreación aquel crecimiento que acompaña todo acto bueno, todo don de sí mismo. Los fines definidos por Santo Tomás son, por tanto, reducidos a la intención subjetiva de los esposos (los motivos o los móviles) o al resultado de sus actos (los efectos materiales).

En este contexto, la finalidad teológica es restringida al horizonte de lo material, el fin primario que es la procreación y la educación de los hijos es desligado del consentimiento personal de los esposos que cualifica a la institución matrimonial. Además, los otros fines secundarios (ayuda mutua y remedio a la concupiscencia) pueden ser reducidos a ser un medio al servicio del fin primario. El lazo entre el amor de los esposos, por una parte, y la acogida y la educación de los hijos, por otra, se desecha. Los teólogos buscarán definir el lugar del amor, de la amistad, de la unión conyugal, de la ayuda mutua, de los hijos. Les será difícil, incluso recurriendo a la clásica distinción entre finis operis y finis operantis, de unir estas diversas realidades respetando el sentido de la doctrina de los fines. El debate llegará a ser más áspero una vez conocidos los descubrimientos biológicos relacionados con los mecanismos de reproducción humana y la posibilidad de disociar el acto sexual de la fecundidad. Estos variados factores formarán parte de los debates acerca del sacramento del matrimonio en el Concilio Vaticano II.

\subsection{Perspectivas institucionales del matrimonio en un nuevo con- texto}

Los aspectos jurídicos muestran poco a poco sus limitaciones al definir la institución matrimonial. Con el correr de los tiempos surgen nuevas interrogantes teológicas: ¿cómo pensar las «propiedades» de la unión esponsal en un contexto socio-cultural, donde la duración del matrimonio aumentaba notablemente o el status profesional y social de la mujer cambiaba profundamente? ¿Cómo evaluar los descubrimientos biológicos acerca del ciclo de la mujer y de las hormonas aptas para regularlo o inhibirlo? Estos descubrimientos mostrarán toda su fuerza durante el Concilio Vaticano II y después de la aparición de Humane vitae. 
Enumeremos algunos elementos constantes y válidos en todos estos movimientos de ideas: la enumeración de los tres bienes del matrimonio, una cierta primacía siempre reconocida de los hijos, la importancia del amor orientado primeramente a la procreación. «No se puede amar sino se ama a alguien, es decir, el amor mismo es siempre objetivo, se dirige a otro distinto de uno mismo (...) Tenemos aquí la expresión a la vez de la caritas agustiniana y el desinterés de la caridad tomista» (Mattheeuws, 1989: 48), dicho de otro modo, el amor es más que un sentimiento, está ligado a la persona que se da, a su libertad que se compromete. Estas consideraciones nos serán útiles para releer la doctrina del matrimonio desde el ángulo del don y para «salir» de una concepción exclusivamente jurídica del sacramento.

\subsection{Período Conciliar}

En el Concilio asistimos a un amplio debate entre los Padres acerca de la doctrina de los «bienes» y la de los «fines», en estas discusiones, cada uno trata de mostrar la importancia y la riqueza de la una y de la otra frente a las nuevas corrientes que desarrollan la importancia del amor conyugal. Si hay debate en el Concilio es porque varios elementos nuevos aparecen en la conciencia contemporánea:

- Un elemento científico: el descubrimiento de los períodos fértiles e infértiles de los esposos, y la posibilidad de eventualmente disociar el aspecto procreativo y educativo de los hijos del aspecto unitivo, como será llamado más tarde.

- Un elemento cultural y social, la longevidad creciente de los esposos y por tanto, de la vida en común, el aspecto de la ayuda mutua, conversación, como decía Santo Tomás, de perfección mutua, toma desde entonces una dimensión radicalmente nueva en el compromiso mutuo. Los cambios de status profesional y la nueva imagen de la mujer en la sociedad se revelan igualmente con un peso considerable para la vida conyugal y matrimonial.

- La profundización de la definición y de la misión del amor conyugal. El amor es reflexionado no solo como sentimiento sino como concepto teológico, como la imagen de lo que es el amor divino entre los esposos. En las dos doctrinas antes citadas, el lugar del amor no era muy manifiesto. Hugo de San Víctor hablaba del amor y fue un precursor en este ámbito, pero en el conjunto de la tradición teológica el lugar del amor no 
había sido desarrollado. Una gran parte del debate conciliar consistió justamente, en encontrar ese lugar.

¿Es necesario oponer, como algunos lo pensaban en 1965, el amor a los «bienes» y a los «fines»? ¿Cómo salir de una dialéctica de prioridad que no se da cuenta de la realidad concreta de las parejas ni de una unidad del pensamiento? ¿El amor, es un «nuevo fin» que reemplaza a los otros o es el fin primario del matrimonio? O bien, ¿es el amor la esencia, el motor de la relación conyugal? Este callejón sin salida parecía ineludible en el Vaticano II y las discusiones conciliares sacaron a la luz las dificultades de comprensión de las diversas doctrinas, así como la aspiración de muchos interesados en el desarrollo de un lenguaje diferente sobre estos temas delicados. ¿Qué podemos destacar?

¿Qué hay de significativo en este debate conciliar? Un silencio. El Concilio ha constatado un cierto silencio sobre las dos doctrinas de los «bienes» y de los «fines». Silencio y desarrollo doctrinal menos amplio que lo previsto. Los textos conciliares hablaban de procreación y educación de los hijos, del amor conyugal, del perfeccionamiento de los esposos, de la ayuda mutua, pero los acentos han cambiado, el vocabulario también. Acerca de los «fines», está claro que se les menciona, pero desaparecieron los calificativos de primario y secundario. El matrimonio está dotado de «diversos bienes y fines» afirma el Concilio (GS 48,1). Sin embargo, la doctrina de los fines no es recordada con fuerza. Ya no se encuentra la distinción hecha por Santo Tomás entre fines primarios y secundarios. Sin embargo, las discusiones fueron apasionadas. Uno puede encontrar numerosos recordatorios de las doctrinas de la finalidad en los textos conciliares, e incluso más tarde si no fuera por la expresión verbal «ordenado a» y por la consideración del contenido de los «fines» del matrimonio. Sin embargo, el vocabulario de conjunto y el acento son relativamente diferentes, la doctrina parece ser reinterpretada a partir del amor conyugal y de la comunidad de vida. El Concilio ha hecho comprensible la esencia del contrato por el amor de los esposos y ha rechazado toda dicotomía entre amor conyugal y matrimonio. Surge de esto una visión más unificada en la cual las exigencias personalistas no están ausentes.

El matrimonio está dotado de «bienes»y «fines»: el Concilio los señaló al menos en general. Sin embargo, no señaló una clasificación de «fines». Lo que no quiere decir de otra manera que sea imposible clasificarlos. La finalidad procreadora está bien destacada en Gaudium et Spes (es mencionada más de diez veces), pero el hijo es presentado de otra manera, y este es uno de los puntos interesantes, los hijos son declarados como el «don» más excelente del matrimonio. El empleo de la palabra donum en lugar de la palabra bonum, destaca explícitamente el deseo de no 
quedar prisionero del esquema tradicional, el de los «bienes», y tiende a abrir nuevas perspectivas. Tal es nuestra interpretación del silencio significativo del Concilio y de su cambio de vocabulario: el Concilio evita poner el acento sobre las terminologías tradicionales del matrimonio. No las reniega pero desea satisfacer una búsqueda contemporánea, presente en la teología y la pastoral conyugal: encontrar una nueva expresión para proclamar la riqueza del amor cristiano y sobre todo del amor en el matrimonio. En una de las enmiendas, cuando se preguntaba por qué la fórmula que definía procreación como «fin» primario no era utilizada, dice explícitamente que se trata de un vocabulario técnico que no conviene utilizar por razones pastorales.

Finalmente, el silencio del Concilio acerca de los «fines» del matrimonio, nos parece significativo no como una «ruptura» de tradición sino como un «alto» ofrecido a la Iglesia por el Espíritu Santo. Este alto ha permitido dejar de lado las confusiones engendradas por las concepciones contemporáneas de la finalidad y evitar así numerosos malentendidos en la enseñanza y la práctica pastoral. Este tiempo de espera ha hecho posibles la integración de nuevos valores tales como "persona», «dignidad», «amor conyugal». Esta etapa constituye una transición entre una doctrina clásica, conocida por todos, y puntos de vista nuevos que solo estaban en ideas o escritos poco conocidos. Pasamos de una descripción de la esencia del hombre, caracterizada por su alma y sus potencias a un lenguaje donde la persona es el principio integrador de la naturaleza humana y de sus actos. La persona será puesta en el centro de la antropología cristiana y por consecuencia de la moral.

Entre los frutos del Concilio, podemos ciertamente notar la influencia de las corrientes personalistas y el uso fecundo de los conceptos de «persona» y de «dignidad». El hilo conductor del desarrollo conciliar sobre el matrimonio ya no es jurídico o institucional. La reflexión doctrinal sobre este tema procede de una consideración de la persona de los contrayentes y de sus actos (GS 47,48 y 51). La persona es un valor en sí: está en la cima de los valores en el orden natural. No puede ser considerada como un medio para obtener otro fin. «Concibiendo el matrimonio como comunidad, el Concilio otorga un lugar mucho más grande a las preocupaciones personalistas, pero sin debilitar su estabilidad. Esta pasa del plan jurídico al nivel psicológico y moral» (Mattheeuws, 1989: 241). Esta presentación implica una ontología de la persona cuya riqueza se desplegará ampliamente en los años ulteriores. El matrimonio, ¿acaso no es un «encuentro personal» marcado por una promesa y un don recíproco ratificados por Cristo? Este tema de la persona en su unicidad es recordado en el llamado a la santidad que resuena para los esposos en el corazón de su estado de vida (LG 11 y GS 48,2). Amándose con caridad 
los esposos llegarán a ser santos. El amor es el que respeta y promueve, en el matrimonio, la dignidad de cada uno. El tema del «don» está presente, también, en los textos de Vaticano II, pero su importancia es poco destacada en los comentarios, no más que su relación con la «libertad». Puede sorprender que tales conceptos «fundantes» queden en la sombra. La historia del pensamiento revela que es necesario a veces tiempo para que una realidad adquiera toda su densidad en la reflexión.

El Concilio ha destacado algo bastante nuevo en la historia dela Iglesia: el lugar del amor conyugal; y no ha tratado de jerarquizar los «fines» del matrimonio, pero ha insistido sobre su unidad inscribiéndolos en la dinámica del amor conyugal. Luego del Concilio, este movimiento teológico se acelera y se ampliará en documentos posteriores. Asistimos a una aceleración de las preguntas sobre el sentido, sobre el significado del amor conyugal, sobre la relación entre el acto conyugal de la procreación y de la unión.

En fin, en el Vaticano II, hemos asistido a un debate sorprendente vivo sobre estas cuestiones. Aparecen novedades: importancia de la persona y del amor. Un silencio relativo sobre los «fines» y sobre los «bienes». Un pequeño cambio para calificar la procreación del hijo: solamente no es un bonum sino que «es el donum más excelente del matrimonio». El Concilio no enseña la clasificación y la jerarquización de los fines que todos los intervinientes suponen. A partir de esta época y hasta la publicación de una catequesis de Juan Pablo II (24 de octubre de 1984) ${ }^{7}$ no habrá referencia explícita a la doctrina de los fines del matrimonio en los principales documentos del magisterio. El Concilio tampoco define «nuevos» fines. En el plano doctrinal, hay un cambio de registro. Comienzan a aparecer nuevas palabras tales como «significado», «valores», «sentido», «don». Si releemos atentamente uno de los pasajes claves de Gaudium et Spes describiendo el amor conyugal y su responsabilidad en la transmisión de la vida, adivinamos la evolución que está haciéndose a través de la argumentación teológica desarrollada: «Cuando se trata, pues, de conjugar el amor conyugal con la responsable transmisión de la vida, la índole moral de la conducta no depende solamente de la sincera intención y apreciación de los motivos, sino que debe determinarse con criterios objetivos tomados de la naturaleza de la persona y de sus actos, cri-

6 Esta última expresión se mantiene discretamente, a través de las discusiones conciliares y en un lenguaje nuevo, la prioridad del fin procreador. Es el testimonio de una mutación profunda en la continuidad, es como una semilla que convendrá hacer fructificar.

7 Juan Pablo II, Catequesis "La virtud de la continencia" en Audiencia General, Miércoles 24 de octubre de 1984 [N. del T.]. 
terios que mantienen íntegro el sentido de la mutua entrega y de la humana procreación» (GS 51,3).

\subsection{Período postconciliar}

Esta etapa postconciliar está marcada por numerosos textos relacionados al tema del matrimonio, o a realidades morales y sexuales relacionadas al matrimonio. Tomemos Humanae vitae, el Sinodo sobre la Familia, Familairis consortio, Donum vitae, La Carta a las familias, Evangelium vitae. Recordemos el inmenso esfuerzo catequético de Juan Pablo II, esfuerzo que se desplegó durante tres años, para describir «el amor humano en el plan divino». Esta reflexión forma verdaderamente un humus intelectual ligado a la persona de Juan Pablo II, lo que nos permite interpretar el conjunto de los documentos magisteriales de esta época. En la línea de este desarrollo destacamos el lugar particular, a nivel de Iglesia universal, del Catecismo de la Iglesia Católica (CEC: descripción del sacramento del matrimonio y comentarios al $6^{\circ}$ y $9^{\circ}$ mandamientos).

Todos estos documentos profundizan la doctrina del matrimonio, enriquecen y también revolucionan el vocabulario, asistimos a una supresión del lenguaje de la finalidad para llegar a una terminología que llega a ser más cercana a la afectividad conservando todo su carácter «esencial», es decir, ontológico. Pensamos en la palabra «significado» utilizada por Pablo VI en Humanae vitae cuando habla del doble significado, unitivo y procreativo del acto conyugal. Sin embargo, subyacen preguntas. ¿Cómo dar cabida a una cierta desaparición de los «bienes»? ¿Cómo olvidar que todo acto humano está dirigido a su término, es decir, cómo reencontrar una finalidad de los actos del matrimonio? A menos que bondad y verdad se abracen de nuevo, y que las palabras «persona y amor» permanezcan unidas, a menos que la palabra «don» parezca como realizando la unidad de lo que resulta disperso o ha sido dispersado por los elementos culturales o intelectuales ${ }^{8}$.

8 ¿Cómo situar la encíclica Humanae Vitae, publicada en 1968, y la intervención del Papa en este campo? Recordemos que Pablo VI ya se había reservado, durante el Concilio, la cuestión de la moralidad de los medios de regulación de la natalidad. Su toma de posición agudiza el paso de la problemática de los fines del matrimonio a la de su acto específico. La terminología de los fines ya no es utilizada, incluso si la finalidad permanece presente. La encíclica se apoya en el Concilio. Pero es momento para el rigor de la norma y a la precisión del mensaje moral más que a la amplitud de la argumentación o profundización temáticas de Gaudium et Spes. Pablo VI precisa en su encíclica el valor del acto conyugal que reside en el carácter indisoluble de sus dos significados: procreativo y unitivo. En lo que respecta al hombre integral, el acto conyugal expresa la esencia del matrimonio, y la unidad indisoluble de sus dos significados la despliega. La acogida de la vida y del amor tienen, como la unidad de los 
En el pontificado de Juan Pablo II se inician las nuevas reflexiones. El Papa ya no habla más de «fines», pero de finalidad del acto conyugal y del matrimonio pasa a ser una «tarea» que es una «misión» eclesial. Los «significados» aparecen explícitamente como «responsabilidades» confiadas al hombre, guardián de sus hermanos. Las perspectivas son más desarrolladas. Los aportes son más ricos que durante el período de las controversias (1962-1968). El Sínodo de la familia de 1980 y la Exhortación Apostólica Familiaris Consortio aportan a este período una riqueza tangible. El pensamiento personal de Juan Pablo II, particularmente su teología del cuerpo, dan un fuerte impulso a la problemática. Comienzan a emerger la unidad buscada en la doctrina del matrimonio y en las diversas preguntas morales que de ella se derivan. Un halo personalista tonifica estas reflexiones. La palabra «significado» manifiesta con fuerza la intuición de un «sujeto» que a la vez «recibe» todo lo que es de un «otro» y es llamado a «dar» sentido a sus propios actos. La intención de los sujetos no puede establecerse desde lo arbitrario pues no es una pura creación humana. Los esposos están llamados a asumir la objetividad del cuerpo y su lenguaje. El cuerpo «dice» la persona. La persona «se dice» a través de su cuerpo. ¿Cuál es la verdad del acto conyugal sino ser un don, un don específico de los esposo, de una persona a otra? Al leer los documentos de este período, ¿cómo no estar interesado en la importancia de la temática del don?

Por supuesto que el lenguaje agustiniano centrado en los bienes expresa de manera feliz ciertos aspectos del matrimonio. Varios autores han mostrado que esta doctrina «impregna» profundamente Gaudium et Spes y diversos textos magisteriales posteriores. En cuanto a la doctrina de los fines del matrimonio no se la reniega totalmente. El silencio de los últimos documentos sobre este asunto, así como los nuevos aportes filosóficos y teológicos, constituye una toma de conciencia de las dificultades de comprensión doctrinal y pastoral. Quizás haya que ir más lejos que estas constataciones. A través de la puesta en evidencia de nuevos acentos y de un vocabulario nuevo, asistimos a la integración y a la pro-

esposos su belleza y perfección morales en esta «unidad» (lo que el autor inspirado llama «una sola carne» en $\mathrm{G} n$ 2,24). Asistimos a la proyección sobre el acto conyugal de lo que estructura el ser mismo del sacramento del matrimonio. Pablo VI utiliza particularmente el vocabulario de los «significados». Este vocabulario no expresa solamente la unidad existencial del corazón de los esposos sino igualmente, la realidad objetiva del matrimonio. Hablar de «significado» es indicar, a la vez, lo que «quieren decir» los esposos en el acto conyugal y lo que «dice» el acto mismo. Si el acto conyugal tiene un «sentido», es porque une la procreación y al unión como dos aspectos «esenciales» de este acto. Este recuerdo, en al Humanae vitae, de la «naturaleza» del acto conyugal y de sus significados testimonian un desarrollo de la reflexión. 
fundización de dos doctrinas tradicionales y a la aparición de una nueva síntesis. Estos cambios de la doctrina de los fines del matrimonio desde inicios de siglo son señales de la investigación y de la puesta en común de un nuevo desarrollo doctrinal. Asistimos a la elaboración lenta y paciente de un nuevo lenguaje de la Iglesia sobre el matrimonio y su acto específico.

Los conceptos de «don» y «donación» son utilizados con una frecuencia innegable, este uso cacaso no reviste un significado aclarador? $\mathrm{Si}$ el Concilio, al hablar de la institución matrimonial y familiar, nos hace recorrer el camino que va desde el «derecho» a la «comunión» poniendo el acento en la persona, su insistencia sobre el don ¿no es preciosa para orientar esta evolución? Pensamos que una nueva doctrina está naciendo: la de los «dones» del matrimonio. Nuestra perspectiva no es iconoclasta, no se trata de un reemplazo de una doctrina «inadecuada» por otra más actual o más adaptada a nuestro tiempo, sino de un enriquecimiento. Pensamos asistir a un desarrollo doctrinal, a un despliegue de una riqueza, antigua y nueva, los «bienes» antes de ser «fines» que esperar, son «dones» que alcanzar.

Dicho de otro modo, una manera de profundizar la doctrina de los fines sería situarla en el movimiento de reditus de la criatura respecto a su Dios, en quien ha descubierto un Padre. La humanidad salida de Dios por amor retorna a Él. La unión conyugal participa de este reditus pues, ella es el «cuerpo» donde este se realiza y se enriquece de vidas nuevas y eternas. En este «cuerpo» personal, todo hombre se experimenta desde el principio como «dado él mismo por Dios». Le es dado comprender que no debe su existencia al azar, ni a él mismo, ni a otros humanos, sino solo a Dios. Si examinamos en detalle la estructura de don del ser humano, esta reflexión permitiría comprender mejor el acto conyugal como participación en este retorno al Padre de aquellos constituidos, desde el principio, como seres-en-deuda de amor. La santidad, ¿acaso no es darse y contar con un otro por amor?

\section{Nacimiento de la teología de los «dones»}

La aparición de todos estos documentos magisteriales es el signo tangible del nacimiento de una nueva doctrina. El «Mysterium» del matrimonio es desplegado bajo la temática del «don». ¿Cómo demostrarlo? Sugiriendo tres pistas: primero, el «don» que es Cristo, enseguida lo que es la persona, como ser de don y, finalmente, la realidad de la espiritualidad conyugal centrada sobre el don de sí. 


\subsection{Eje cristológico y pneumatológico}

La temática del don nos remite a cuestiones fundamentales, dónde el beneficiario del don está en frente del donador, dónde el vínculo puede ser unilateral o bilateral, dónde el intercambio de dones puede asegurar la finalidad de una vida o el gesto de «dan» puede estructurar la personalidad o la identidad de una familia, de un pueblo. Nos lleva nuevamente hacia el misterio de Dios Padre que ha deseado ofrecer a la humanidad el rostro de su Hijo y hacernos entrar en su intimidad. Esta gratuidad divina, expresada en la historia humana, también cuestiona. Toda fenomenología del don remite como por connivencia amistosa a una teología del don. Esta aclara, estimula y fortifica todas nuestras observaciones y consideraciones relacionadas con la convivencia humana. El amor ¿no revelaría una parte de su misterio a través de la circulación del don que sostiene nuestra vida cotidiana?

El lenguaje de la Revelación Trinitaria debe ser considerado pues, si el Padre nos dona a su Hijo, pone delante de nuestros ojos al Hombre perfecto, el nuevo Adán. La persona del Hijo, Imagen y Don por excelencia, se encuentra en cada ser humano. Uniéndose a todo hombre (G.S $22,2)$ el Verbo encarnado revela al hombre a él mismo. La reflexión teológica de este siglo se complace en meditar al hombre a la imagen de Cristo, la Imagen y Don del Padre. El Verbo hecho carne es teofanía de Dios divino. Su vida, sus palabras todos sus «misterios contemplados», como diría San Ignacio de Loyola, entregan la plenitud del don trinitario acogido por su Iglesia. La simbólica nupcial del don de Cristo a su Iglesia es la referencia fontal y única de todo don y de todo ser humano.

Los textos del último Concilio celebran además en esta luz crística la grandeza de la persona humana, «la única criatura sobre la tierra que Dios ha querido por sí misma» (G.S 24), el hombre no «puede encontrarse sino por el don desinteresado de él mismo» (G.S 24). Las personas humanas, en su masculinidad y en su femineidad, están destinadas a amar entregándose. Su don conyugal «significa» un don personal y libre. El hombre está llamado a cumplirse dándose como las Personas divinas de las que él es imagen en la Creación.

La reflexión central de GS sobre la persona de Cristo, verdadero Dios y verdadero hombre sostiene también la aparición de los últimos documentos de moral familiar. En Cristo, podemos ver manifestadas las características fundantes del ser humano. «He aquí el Hombre» (Jn 19,5). Pero también, «Verdaderamente, este hombre era Hijo de Dios» (Jn 27,54). Él es el don de Dios. No hemos esperado veinte siglos de cristianismo para saber que Jesús es el hijo de Dios y que es el Don de Dios. La temática del «don» estaba explícita en la teología bíblica y dogmática y 
como que se ha desplazado, en nuestra opinión, para alojarse profundamente en el campo sacramental y en el corazón del matrimonio.

El misterio de la Encarnación, descrito con tanta riqueza en el famoso Prólogo de San Juan, funda toda reflexión sobre el Hombre-Dios que es el Verbo de Dios hecho carne como «don» de Dios. Un Hijo nos ha sido dado. Esta evidencia del «don» de Dios en Jesucristo va a salpicar sobre toda la sacramentalidad de la Iglesia (la Iglesia Sacramento), sobre los siete sacramentos y sobre la doctrina del matrimonio. ¿Cómo reflexionar, ahora, el amor de los esposos al interior de este gran misterio de la relación de Cristo con su Iglesia, de Cristo dado «como un esposo» a su Iglesia? La economía de la salvación es reflexionada como nupcial. Así, hablar del matrimonio, de sus «bienes», de sus «fines» y de sus «dones», es hablar al interior de una relación nupcial. Jesús es el Esposo. Jesús es el «don» ante todo. Por otro lado, este «don» es también escatológico pues indica claramente cuál es la finalidad, cuál es el omega de toda generosidad divina. La relación hombre-mujer y la del hijo se sitúan en el orden sacramental, es decir, en el orden del «don» de Cristo a su Iglesia, en el orden del deseo de Dios, de su plan creador y redentor. El amor ¿no es vivir ya la eternidad sobre la tierra y darse uno a otro con este objetivo? En este contexto, el amor, definido de una manera más explícita en el Concilio Vaticano II, ya no arriesga ser comprendido como un simple sentimiento o un deseo subjetivo. El amor es esta voluntad de recibir el «don» primordial hecho en Jesucristo y en su Iglesia. El crecimiento de la fecundidad del matrimonio y la fecundidad del amor estarán siempre en el orden del «don». Así, la problemática del hijo que aparecía antes como «fin esencial primordial» (¿es la única finalidad del matrimonio?, ¿se casan solo para tener hijos?) y la problemática de la esposa instrumentalizada para este fin, es superada por un horizonte de «don» cristológico?.

Cristo origen todo «don» funda nuestra capacidad de darnos unos a otros, particularmente en el matrimonio. Los esposos están unidos en el Señor, este es el horizonte de su «don» se lo encuentra de manera más explícita y mucho más central en el capítulo 5 de la Carta de San Pablo a los Efesios. Los esposos están unidos en el Señor; ellos no se unen para tener un hijo, sino porque están unidos en Cristo, descubren en el hijo el fruto y el sello de su unidad y de su «don» mutuo.

9 En este sentido, las palabras proféticas de Pablo VI a los Equipos de Notre Dame en 1970 adquieren una luminosidad nueva. El papa Pablo decía que el hijo no es solo lo que vemos sino lo que creemos que él es: un hijo de Dios. El hijo, como nosotros, es hijo adoptivo, hermano de Cristo. Estas palabras de Pablo VI sostienen toda su densidad a partir de Cristo. 
La pista pneumatológica, el don que es Espíritu, los dones que nos dispensa, fortifica el eje cristológico. No hacemos más que esbozarlo. La obra del espíritu es de santificación. Sabemos cuánto este llamado a la santidad resuena con fuerza en numerosos documentos conciliares. El Espíritu es aquel que da la vida y el ser; también es el «don» por excelencia. En la teología de Santo Tomás sus nombres son «amor» y «don». Comparte el «don» que está en el pueblo de Dios en camino, con todos los «dones» particulares hechos a cada uno. A cada uno según la misión recibida y en el estado de vida al cual ha sido llamado. Así, el «don» es resultante del Espíritu Santo en todo el pueblo de Dios que llega a ser «don» él mismo ofrecido al Padre. Este llamado de la vocación común a la santidad, esta insistencia sobre la gracia bautismal, esta inhabitación del «don» del espíritu, esta apertura al «don» particular para la misión...y otros temas particulares e importantes del Concilio que ayudarán a desarrollar una nueva visión del matrimonio; fortifican la convicción, de los esposos y de los miembros de todas las familias, de ser llamados a vivir de esta fuente de santificación. La palabra «gracia», entonces, ¿sería sinónimo de don? Los esposos, ¿no están llamados a darse el uno al otro y a Cristo para la mayor gloria de Dios?

\subsection{La instancia personalista}

Se ha hablado mucho del personalismo que sostiene la mayor parte de las investigaciones y la elaboración de numerosos documentos durante el Concilio. Ha sido dicho y redicho que Vaticano II es un concilio personalista. Algunos han incluso subrayado históricamente la influencia del cardenal Wojtyla en la redacción de un documento como Gaudium et Spes. Su reflexión, en efecto, sobre lo que es la persona había comenzado mucho antes del concilio (véase, Persona y Acto). Ella se prolongó desde entonces en varios documentos magisteriales que llevan su impronta. Desde el Concilio, el camino estaba trazado, pero el concepto mismo de «persona» ha revestido varios sentidos. Apareció una polisemia del personalismo cristiano. En nombre del «personalismo» algunos autores llegaron a resultados contradictorios. Así, según los autores, «el bien de la persona» puede recubrir en moral contenidos teológicos o acentos pastorales muy diferentes.

Pocos autores han destacado, nos parece, el lazo existente entre la palabra «persona» y la palabra «don». Este lazo es fundamental en la reflexión sobre el matrimonio. Ya lo era en el pensamiento del Cardenal Wojtyla y sobre todo más tarde, en el pensamiento de Juan Pablo II, el «don» cualifica a la persona. En efecto, el don, como el origen, significa la persona. 
La persona es un ser de «don»; está dada a ella misma por su Dios en su ser corporal. Toda la reflexión del Papa sobre la sexualidad lleva a dar cuenta de este hecho (que «hace sentido»): que el hombre es creado como persona, pero para darse. Cuando el Papa Juan Pablo emplea términos como: «la estructura esponsal del hombre» o bien, «su ser en alianza» equivale a decir que el hombre tiene una estructura de «don». El personalismo de Juan Pablo está especificado por la temática del «don». El don caracteriza y enriquece «la naturaleza misma de la persona y sus actos» (G.S 51,2). Hablar de ser humano en estos términos, participa del trabajo de la Iglesia que defiende la dignidad de la persona y que es don en sí misma, para los otros y para Dios.

Por ejemplo, si Juan Pablo II despliega una teología del cuerpo, es para demostrar que el hombre está dado en su cuerpo. El hombre, esta «imagen» de Dios en su masculinidad y en su femineidad, es hombre porque está dado a sí mismo y confiado al cosmos. Por eso será dado a la mujer o recíprocamente en su cuerpo. El símbolo del «don», que está como persona, y su dignidad intrínseca son justamente manifestados en su ser corporal y sexuado.

\subsection{Una espiritualidad conyugal}

No se puede dejar en silencio la influencia de una corriente espiritualidad conyugal, la de los Equipos de Notre Dame, fundado por el sacerdote H Caffarel. Esta corriente desde hace años está marcada por la temática del «don» y ha transmitido esta sensibilidad al corazón del Concilio; en sus inicios el P. Caffarel había deseado transmitir a los Padres Conciliares la experiencia vivida entre los hogares en Francia, Bélgica y Canadá. En su suplica por una espiritualidad conyugal específica, trataba de mostrar el lugar del acto conyugal en la vida de los esposos. Así se expresaba en una breve nota aparecida en la Nouvelle Revue Théologique: «El acto conyugal es la expresión y la actualización del acto interior de dos personas dándose la una a la otra. La esencia de este acto es ser, a la vez, ‘don' recíproco y 'don' común. Darse el uno al otro para darse juntos teniendo en cuenta que el 'don' recíproco no es un simple medio en relación a este 'don' común, sino que el 'don' recíproco y el 'don' común son un solo mismo acto». Proseguía diciendo: «Porque ellos se aman, sin amor, este 'don' es ininteligible, los esposos se entregan el uno al otro no solamente en vista de una pertenencia mutua (que más tarde se llamará significación unitiva), sino, al mismo tiempo y de manera indisociable, en vista de un 'don' común al otro».

Prestando una importancia histórica a este escrito del fundador de los Equipos de Notre Dame, subrayamos que la reflexión concerniente a 
la doctrina del matrimonio surgió también de la experiencia del pueblo cristiano y de los hogares. El lenguaje que ellos usan y que traduce su experiencia se encuentra con otros desarrollos sobre el don en el discurso de Pablo VI a los Equipos de Notre Dame en 1970. Es este discurso, que se designa habitualmente como el comentario espiritual y escriturístico a la encíclica Humanae Vitae, la temática del «don» está muy presente. Pero esta encíclica no produce todavía todas las armonías, pues todos los instrumentos de la orquesta no funcionan plenamente, será Juan Pablo II quien va a hacer sonar la música del «don». En el lenguaje de Humanae Vitae la finalidad era menos aparente y el concepto de «naturaleza» provocaba problemas de comprensión aun cuando todo estuviera centrado en la norma de la contracepción. Pablo VI hablaba todavía y siempre del amor y de la verdad integral del hombre. Al igual que un eco, Juan Pablo II hará un esfuerzo inmenso para dar cuenta de esta doctrina enfatizando la belleza y la bondad del matrimonio. Sus catequesis, que ya hemos citado, dan cuenta de ello. Numerosos otros numerosos textos manifiestan esta «reanudación» de la doctrina con un nuevo acento, el del «don».

Lo más sugestivo en todos estos documentos es que la palabra «don» acompaña la descripción de la persona frente a su Creador y Señor; enseguida de la persona frente a la Trinidad. Su uso compromete la reflexión del lector hacia la contemplación del único don divino que es el Hijo en las manos del Padre. El ser del amor es «don». Dicho de otro modo, el amor es especificado, toma el rostro del «don»; por el «don» se hace visible en el hombre. Por ejemplo, Familiaris consortio afirma que en su realidad más profunda el amor es esencialmente «don» (FC 14). El amor se dice por y en el «don». El amor es el fruto de un «don» mutuo. El término de «don» se encuentra por todas partes, para designar la realidad matrimonial en sus diversos aspectos. El «don» mutuo del hombre y la mujer está arraigado en la vida íntima de Dios, la persona que ama se da como lo hacen el padre, el hijo y el Espíritu Santo. Si hay «imagen», esta consiste en este amor y en este «don» trinitarios. La persona humana aparece cada vez más como aquella que se da, aquella que está destinada «de suyo» a darse para cumplirse. Cada uno está destinado a amar, es decir, a darse y el «don» carnal significa este «don» personal.

Relacionando la vida humana al creador, dador de toda vida, toda vida humana aparece más claramente fundamentada en el «don». La vida de cada uno aparece con mucho más fuerza como un «don», fuente del derecho fundamental. Este derecho es debido a cada hombre porque está dado por Dios desde el origen. Si el hombre es inviolable es porque no es él mismo sin Dios y porque es Dios quien le da el ser. La vida humana pertenece a Dios, esta vida, este «don» ofrecido, es un signo del ser personal de todo hombre y de su dignidad. 
En la relación hombre-mujer también es importante el vocabulario del «don», el ser humano en su masculinidad y en su femineidad y como esposos, es propiamente imagen del «don» de Dios. Los esposos pueden reflejar esta relación trinitaria. Lo que coincide en Dios, ser y amor, unidad y fecundidad, está unido de una manera absolutamente particular en la relación hombre-mujer. El acto conyugal podrá entonces ser percibido y enseñado como un acto que participa realmente y concretamente en el misterio trinitario. Este lenguaje era inconcebible hace cuarenta años.

El lazo de dependencia ontológica en el «don» que une a la creatura al creador, permite comprender igualmente cómo, por qué y en qué condiciones el acto creador divino de una nueva persona se conjuga con actos realizados por el hombre y la mujer respetando la especificidad de este «don». Todo el misterio de la procreación se vuelve a plantear con su exigencia ética. El hijo mismo pasa a tener voz en este capítulo y la Iglesia habla en su nombre y Pablo VI había reafirmado su belleza de hijo de Dios en nombre de la Revelación. Bajo el pontificado de Juan Pablo II, la reflexión acerca del status del hijo en el seno de su madre y el lenguaje del «don» para cualificar este hijo llegan a ser ineludibles. El hijo aparece como persona completa desde su concepción. Es un ser de «don» y Juan Pablo II, ya sea en sus catequesis o en la exhortación Familiaris consortio, insiste a tiempo y a destiempo sobre la realidad de «don» que es el hijo en sí mismo. Es un «don» en cuanto tal. La insistencia de estos últimos documentos habla también sobre las condiciones de «don» que deben asegurar su llegada a la existencia: «los esposos en cuanto se donan el uno al otro, donan, más allá de ellos mismos, un ser real, el hijo, reflejo vivo de su amor. La vida humana es un 'don'» (FC 14).

El hijo es presentado a la vez como persona, explícitamente como un «don», no solamente en su nacimiento sino desde su concepción y durante toda su gestación. No se trata de algunas indicaciones puntuales del documento sino de una verdadera trama lingüística que compone el tejido literario del documento. La persona es un «don» y es en cuanto «don» que debe ser respetada. Su relación inmediata con Dios es una relación de «don», la vida de cada uno es un «don», el hombre y la mujer deben darse el uno al otro para crear las condiciones de la llegada de un nuevo ser vivo, de un nuevo «don» personal.

\section{4. ¿Una doctrina del «don»?}

Pensamos que durante estos últimos años, particularmente a partir de Vaticano II, se evidencia una «reflexión nueva». Esta reflexión integra las doctrinas tradicionales mostrando un avance doctrinal. Los «bienes» del matrimonio permanecen (CEC 1643), pero son «dones» (GS 50,1) 
antes de ser «significados» (HV 12) y «valores» (DV I, 3; II B4) $)^{10}$, «exigencias» (CEC 1643) y «fines» (CEC 2363, 2366). «Bienes», «dones», «significados», «valores», «exigencias», «fines», todos estos términos expresan un avance en la percepción de un misterio que está en el origen de «todo don».

La persona, de los esposos y la del hijo, se constituye como un ser de «don», como un ser de espíritu, y es en el verdadero «don» de sí donde se realiza toda persona. Del «don» de sí en el amor proceden entonces por añadidura toda fecundidad y todo «don» de vida. El aspecto de procreación surge de una abundancia y no de un deseo, de una necesidad, de una finalidad que sería percibida como una necesidad. Es del amor de los esposos, en el corazón del «don» de los cuerpos, que puede y debe brotar la persona del hijo (FC 14,32). Vemos verdaderamente que hay una especie de maduración en la reflexión, algo ha madurado, ha tomado forma. Asistimos a un desarrollo doctrinal que interesa al matrimonio y a sus exigencias de vida en la verdad. Explicitemos esta tesis.

\subsection{Una «novedad doctrinal»}

Retomemos los tres bienes agustinianos a la luz de la teología del don. Lo hacemos desplegándolos de una nueva forma. Veamos primero ¿qué es la fides? Fides no es sino ese reconocimiento mutuo del hombre y de la mujer como «don del uno para el otro». Este reconocimiento impregna todo su ser, se descubren ordenados el uno al otro en sus cuerpos, masculinidad y femineidad, hasta llegar al cuerpo a cuerpo de la relación conyugal. La libertad personal que consiente en darse pone en medio el juego de los instintos y el mecanismo de la seducción, para cada uno de los esposos la libertad dada a sí misma se hace palabra que compromete en una promesa y una donación recíproca: «solo un ser libre puede dar, de otro modo él cede» (Folscheid, 1991). El don del hombre a la mujer y recíprocamente, es el don de una alteridad dueña de sí misma, confiada en espera de una comunión. La consistencia espiritual de la relación hombre-mujer es del orden del don a pesar de las heridas y de los rechazos sufridos. El don trasciende toda lucha ${ }^{11}$. La complementariedad no es solamente funcional, es ontológica, propiamente personal.

10 Juan Pablo II, Congregación para la Doctrina de la Fe, Instrucción Donum vitae sobre el respeto de la vida humana naciente y la dignidad de la procreación. Respuesta a algunas cuestiones de actualidad, 22 de febrero de 1987.

11 Hacemos referencia aquí a la dialéctica Amo-Esclavo y a su superación por la del hombre y la de la mujer magníficamente expresada por G. Fressard. 
La identidad de uno no puede obtenerse a expensas del otro tanto en el matrimonio como en toda comunidad de seres humanos.

La palabra de consentimiento recibe al otro como don. Dándose a él, ella compromete todo el ser de su cuerpo y por su cuerpo. No es suficiente entregar su cuerpo, es necesario entregarse en SU cuerpo. Lo sexual debe ad-venir personal. El sexo es «altruismo inserto en nuestra carne», dice $\mathrm{M} \mathrm{Zundel}^{12}$. Este abandono sin condiciones de todo ser personal es un criterio de verdad de la relación conyugal. El acto conyugal es el lenguaje carnal de un don recíproco, total y definitivo. Une a los cónyuges suscitando otro don. La relación conyugal es el lugar de una tarea humana, pues, por ella, la mujer engendra al hombre mismo (y recíprocamente) y, al mismo tiempo, son dadas las condiciones humanas de un nuevo ser humano. Lo vemos a la luz del don, la indisolubilidad es un «no retorno» en el acto de donarse, pues no se sabría, a la vez, donarse o restarse. En total pertenencia, selladas por las libertades que Dios les ha dado, el hombre y la mujer están llamados a ser fieles uno al otro y a Dios. Citando a Gabriel Marcel, estas son las exigencias de una «fidelidad creadora». Es necesario el tiempo. El don del instante se funda siempre en la memoria de un don original para esperar un don nuevo en el futuro aún desconocido. El tiempo está dado para que el hombre se ejercite en ser el don que él es.

$\mathrm{El}$ amor surge de las libertades que se ofrecen, es gratuito. Al don de los esposos corresponde el don del mismo Dios: el sacramentum. El sentido del sacramento del matrimonio en la Iglesia se profundiza en esta teología del don. Comprende el «mundo nuevo» de los sacramentos, exige la atención a Cristo Primer Sacramento y su acogida en la IglesiaSacramento. En este sentido eclesial, todo sacramento es nupcial, es decir, un acto del Esposo (Cristo) y de la Esposa (Iglesia) que se dan y se acogen. La unión conyugal encuentra su fuente sacramental en la lianza que el Esposo teje en el espíritu con su Pueblo. El Espíritu como Don personal confirma este don mutuo. No se superpone ni a Cristo ni a la Iglesia sino que es el lazo personal y sustentador en el cual y por el cual se realiza todo intercambio de dones. La relación conyugal se inscribe en este flujo y reflujo del don y encuentra allí su confirmación y su validez. El ritmo de la celebración litúrgica y sus bendiciones atraen a los contrayentes y a la asamblea en este reconocimiento del don.

El punto centrales el compromiso libre de los esposos, el consentimiento. Es una donación mutua. Hacemos presente aquí la tradición del Sur de Francia en los siglos XIV a XVI: la unión de las manos y las palabras de los contrayentes dicen el «don» y lo realizan. Cristo, se dona allí e 
impregna este «sí» con su sello. El consentimiento es una donación activa y dialogada, los verbos mismos traducen la lógica del don en acción. Participando del don original dado en Cristo y en su Iglesia, la relación conyugal está marcada por la unidad y los celos del amor divino. La promesa de fidelidad es promesa de "permanecer don del uno para el otro» a imagen del don de este matrimonio hecho por Cristo a su Iglesia. La fidelidad crecerá en el don y en la circulación del don. El don llama al don. El don herido llamará al perdón.

El sacramento dice más que nuestras pobres palabras humanas, incluso cuando son performativas, el sacramento profesa que Dios, en su Cristo, precede a los esposos en la lógica mutua del don. Los da uno al otro. «El ser amado no es un dios, pero un don real marcado por la presencia del Donador» (Crespy, Evdokimov \& Duquoc, 1966: 82). La indisolubilidad del don mutuo es un signo, a través de la fragilidad y las traiciones de los compromisos humanos, del don original de Dios, de su sabiduría y de su poder. Cristo.-Don habita el lazo personal de los esposos. Siguiendo la lógica de la historia de la salvación, la ley del matrimonio es la eucarística, es decir, entregarse como Cristo se entrega.

Contemplamos finalmente al hijo, la proles, como fruto de este don mutuo de los esposo. Las ambigüedades del deseo de un hijo son numerosas tanto a los ojos de muchas ciencias humanas como a los de la teología pastoral. En toda lógica, una suma de deseos no constituye un derecho. Si el hijo es también un ser-de-don, y no es un deber sino la única creatura que Dios ha querido por sí misma, su concepción como los cuidados que requiere le confiere derechos. El don que es el hijo, constituye la cumbre de todos los derechos que hay que reconocerle. En el marco de la vida conyugal, como en el de las instituciones sociales, en las cuestiones delicadas y complejas de la investigación y desarrollo científico, el hijo nos interpela en su existencia, su cuerpo, su vida, su patrimonio genético, su necesidad de ser llevado, ser puesto en el mundo, educado, etc. Su vulnerabilidad forma parte de la verdad en el debate sobre su status o más bien sobre su misterio. Es el «don más excelente del matrimonio» dice Gs 50,1, y el más gratuito, agrega DV. El reconocimiento apela a un amor humano que encuentra a veces difícilmente el respeto debido en justicia a otro ser humano, particularmente el más pequeño, el más débil. El hijo es fruto del amor y signo de esperanza, si es fruto de un don recíproco de amor llega a ser a su vez, para los padres, un don, un don para ambos, un don que «brota del don» (Juan Pablo II, 1989).

El hijo no es, como diría Heidegger, «arrojado al mundo» desde su concepción, él es «confiado» a la humanidad. Esta humanidad es una madre y un padre. La grandeza invisible del hijo, su misterio "personal», el lugar que le está reservado por la razón y en los corazones, nos inter- 
pelan siempre y manifiestan la calidad de nuestros amores humanos y el grado de nuestras civilizaciones. La manera de mirar al hijo cataliza, a la vez, los fantasmas contemporáneos más comunes, la esperanza que sostiene la relación hombre-mujer, la adopción tierna y sobrenatural de Dios.

El hijo es «inconcebible» (en el sentido etimológico del término y en la consciencia de las implicaciones éticas del acto conyugal) sino en el reconocimiento del propósito de amor personal que preside su existencia. El hijo, para la fe cristiana, es la imagen de ESTE hijo que es Jesús. En todo hijo de los hombres, Dios contempla a Su Hijo pues, según las acertadas palabras del P. Sertillanges ${ }^{13}$, «nunca la humanidad ha estado sin su Cristo». Todo hombre es creado en Cristo. El don de Dios no está en la grandeza, es vulnerabilidad, debilidad, silencio. El hijo es el rostro frágil de la sobreabundancia del don. Él provoca en sus padres y en la humanidad otra mirada, les pide que lo amen y les ordena amarlo.

\subsection{Las ventajas de tal doctrina}

¿Cuál es el interés de esta temática del don para el sacramento del matrimonio? ¿Cuál es la fuerza de un «don» o del lenguaje del «don»? me parece que esta óptica manifiesta siempre el origen, existe un donador, el horizonte del ser es pura gratuidad, la libertad humana está en «tener la bondad de hacer algo» en relación con su propia existencia. Desde un punto de vista filosófico, C. Bruaire ${ }^{14}$ hablará del hombre como un «ser no arrojado al mundo» (como dice Heidegger) sino de un ser «confiado al mundo» ${ }^{15}$. Desde un punto de vista teológico, percibimos que no estamos solamente confiados al mundo sino que hemos sido puestos gratuitamente en la existencia por un Padre que nos ama sin mérito nuestro y sin que podamos hacer nada al respecto. Hablar del «don» es manifestar un origen totalmente gratuito. Por otra parte, en el orden del tiempo presente de la historia, esto vuelve a "obligar a la libertad personal" de

13 Antonin-Dalmace Sertillanges, (1863-1948), también conocido como AntoninGilbert Sertillanges y Antonin Sertillanges, fue un religioso dominico, filósofo y teólogo francés, considerado uno de los máximos exponentes del neotomismo en la primera mitad del siglo XX [N. del T.].

14 Claude Bruaire (1932-1986) filósofo católico francés, cofundador de la Revista Communio y uno de los representantes de la renovación de la filosofía cristiana y de la cristología en los años 70 [N. del T.].

15 Bruaire ha escrito una obra metafísica particularmente original: El ser y el espiritu. Estamos llamados en razón a fundarnos sobre esta perspectiva para comprender mejor lo que es el absoluto del espíritu y por ello lo que es el hombre, como ser de espíritu y de don. Invitamos al lector a profundizar esta reflexión leyendo nuestro análisis en Mattheeuws, 1996: 27-124. 
cada uno, obligarla en un sentido de «tener la bondad de hacer algo» y de «obligación». La historia personal de cada uno de nosotros está dinamizada por una deuda de amor no en lo que tenemos sino en lo que somos.

Toda exigencia moral está llena de una gratuidad que cuestiona. Toda persona que se descubre como persona y como ser de «don», se descubre lista y capaz para tener la bondad de darse. En el «don» reside todo amor. Hablar de «don» en la Historia es dar cuenta de una libertad humana que tiene la bondad de hacer algo, que está «asombrada» delante del «don» que ella es y el «don» que ha recibido. Manifestar el origen, obligar a la libertad, es también dar un horizonte para el don, es decir, una bienaventuranza, un término de amor, reencontramos así la finalidad que está siempre presente. ¿Cómo devolver todo bien recibido sino dándome yo mismo a aquel que me ama? Así entre el bonum de Agustín y la finis de Tomás ha surgido, me parece, el donum del amor, de la persona, del hijo, del sacramento, de la presencia de Cristo y de la Iglesia en el matrimonio.

Para decirlo de otro modo, el ser de «don» que somos hace «memoria» siempre del «don» que se es, del «don» que se ha recibido de la vida, del «don» que es el mundo en el cual se está, del «don» que son los otros. Pues el dinamismo del «don» no es un olvido del origen, al contrario nos lleva por «memoria profunda» a lo que somos en verdad. Al contrario, hunde sus raíces en la toma de conciencia personal y siempre más profunda del «don» en el origen de cada ser.

Ya sea en el vientre materno, ya sea al interior de las manipulaciones técnicas de fecundación, el ser que viene a la existencia es un ser dado por sí mismo por un acto de «don» del creador. Y este «don»sobre el cual cada uno de nosotros no tiene ningún control salvo en la acción de gracias y a través de la libertad de asumirlo, es ciertamente un «bien». Él manifiesta en su gratuidad una bondad de ser. El ser es bueno. Dios es bueno y Dios se comunica como bondad, como amor. Él diseña sin cesar una bondad original, una «creación» un estado de armonía, querido así por Dios, amado así. Esta bondad original, es verdaderamente el retorno y el recuerdo de los primeros capítulos del Génesis, de esa creación donde éramos armonía, de esa decisión buena de un Dios que nos ama y que nos quiere «bueno» como creatura. Así, este dinamismo del «don» en el tiempo presente no borra el pasado o las primeras páginas del génesis, al contrario, nos transporta al memorial de aquellas páginas. Es necesario que entremos en las «entrañas» del Dios creador y en sus afirmaciones letánicas: «Y vio Dios que era bueno...era muy bueno» (Gn $1,31)$. 


\section{Integración de estas doctrinas}

Los «bienes» del matrimonio, ¿acaso no son fines porque primero son «dones»? ¿Qué llegan a ser estos bienes en una teología del don?

El don, cada vez que es citado, recuerda de alguna manera sin negar las debilidades y el pecado el hombre, la doctrina de los «bienes». Lo hace en el tiempo presente, ahora a través de toda la convicción en nuestros espíritus que existe un plan de amor de Dios, que el hombre es bueno para la mujer y que la mujer es buena para el hombre. Que su unidad es un punto culmine de la creación cuando ésta es asumida verdaderamente en toda su grandeza, positiva y libremente. Me parece que el dinamismo del «don» recuerda, ya sea en el Antiguo Testamento o ya sea en boca de Jesús en Mateo 19, la bondad de la relación hombremujer sean cuales sean las apariencias históricas que ella revista. El don recuerda la fecundidad bendita de esta relación (prolis) su misterio de armonía, su fuerza de compromiso indisoluble (fe indefectible o fides) en el cual Dios Mismo está presente y desea siempre hacerse presente a través de la Persona del Salvador (sacramentum). Dios mismo en Jesucristo es el «don» por excelencia en quien reposa todo otro don.

Sin embargo, si el dinamismo del «don» hace memoria del origen en el tiempo presente, hace memoria para orientar hacia el «fin». Si el hombre se descubre dado a sí mismo en su cuerpo y si, en su libertad, descubre que no puede cumplirse si no es dándose y que todo rechazo en el «don» es una manera o bien de destruirse o bien de no construir el hombre que es, al final se encuentra la felicidad, al final se encuentra la conclusión de un «don» total de sí mismo al amor que lo hacho venir a la existencia. La finalidad aparece desde que se habla de «don», cuando se habla de «don» se habla de un orden al «don» de sí y en el amor. «Estoy llamado a darme para cumplirme», «estoy en deuda conmigo mismo y siempre en búsqueda para dar gracias del 'don que soy'». Y me activo, y veo el final de mi felicidad en el «don» que hago de mí mismo, en la posibilidad que tengo, después del acto de Cristo, de poder saldar la deuda que soy y de poder verdaderamente entregarme como Él, enteramente. Me parece que a través del «don» es recordada de manera explícita la finalidad de nuestro ser. La finalidad del hombre y de la mujer en su relación.

Este «don» sugiere que el hombre no pueda ser llenado sino por solo por Dios. Pero todo acto presente de «don» espacialmente el sacramento del matrimonio es una etapa para re-entregarse y para entregarse por entero. Si Dios está al final del «don» toda nuestra vida tiene un sentido en el «don» que hacemos. Todas las propiedades clásicas del matrimonio, que recuerda el Derecho Canónico, fidelidad, indisolubilidad, unidad, 
son una manera de poner la finalidad en el presente mediante el «don». $\mathrm{El}$ «don» fiel e indisoluble manifiesta la felicidad que me ha sido prometida en la eternidad, pero que ya me es ofrecida en el presente si yo me entrego en esta fidelidad. Así, el «fin» de nuestro ser, sean cuales sean las modalidades de expresión, es decir, su estado de vida, no pertenecen primeramente una moral negativa, a exigencias extrínsecas o a prohibiciones sino a una moral positiva, de la bondad del ser, un ser de «don». Todos estamos llamados a dar libremente y para nuestra más grande felicidad, la alegría de aquellos que amamos, la alegría del hombre y de la mujer, la alegría de los niños, a dar todo a Dios. La bondad de realizar el «don» que somos en el origen nos empuja a darnos, a dar todo y a ser feliz en el «don» que somos.

\section{La originalidad de este desarrollo}

Nuestra relectura de los «bienes» del matrimonio a la luz del don es nueva en más de un sentido. Se destacará sin duda el cambio operado en el orden de presentación de los «bienes». Manifestamos primero la importancia del reencuentro del hombre y la mujer, como personas capaces de darse el uno al otro. Cristo se hace presente en el corazón de este acto libre y se entrega a fin que el amor de los esposos sea un signo privilegiado de su alianza nupcial con su Iglesia. Finalmente, en esta plenitud de gracia y presencia mutua surgen los hijos, el don más grande y más gratuito del matrimonio (DV II B, $\mathrm{n}^{\circ} 8$ ), para coronar «como por añadidura» las personas comprometidas por amor. El hijo es un don en la medida del don ya realizado, un don de suyo porque es personal. En esta presentación, el acto conyugal no puede ser instrumentalizado, condicionado en vista de la acogida o rechazo del hijo. Si es fecundo es porque es un acto de amor y de don. Tal es la procreación digna del hombre.

Esta teología del don hace referencia a tres conceptos fundamentales: persona, don y amor. Bajo la forma de conclusión, desarrollaremos su importancia e implicancias en el presente.

¿La libertad es un punto neurálgico de la modernidad? Desde Descartes, Kant y el idealismo alemán, el pensamiento está centrado en el sujeto y la libertad. La libertad define al hombre y el hombre es definido por ella. Si la palabra «persona» responde a numerosas cuestiones contemporáneas sobre los derechos del hombre, ella no surge de manera aislada pues la palabra «don» le ofrece una armonía suplementaria. Afirmamos pues, que la persona es el amor que se d entrega. La persona es un don amante. La libertad del ser humano es darse. El hombre se realiza dándose. Como lo dice Gaudium et Spes 24: «El hombre, única creatura en la tierra que Dios ha amado por sí misma, no puede plenamente encontrar- 
se sino por el don desinteresado de sí mismo». Cuerpo, corazón y espíritu son comprometidos libremente en la persona que se da. Hablar de un ser-de-don es significar la recepción del don que es cada uno, por consiguiente la acogida del otro por la puesta en acto del don que somos. Por la libertad, la persona llega a ser el don que está en el origen. En el conocimiento de este origen «dado», el hombre marcha libremente hacia la bienaventuranza eterna. El fin no existe sin el origen y la vida es don en libertad. R. Habachi ${ }^{16}$, filósofo libanés, testimonia la misma verdad: «Pero, retengamos, dice él, que el hombre no comienza sino con el don porque este es el hijo de la libertad». Don y libertad se engendran mutuamente. Tales son algunas afirmaciones centrales de la teología del don.

Por otra parte, en la historia del sacramento del matrimonio, señalábamos el surgimiento de una nueva doctrina, la de los dones del matrimonio. Insistimos en la originalidad y la coherencia de esta avanzada doctrinal. Atestiguamos su sorprendente fecundidad. El término don es «englobante»y ha fecundado otros tales como «persona», «dignidad», «amon». El don es la persona que ama. El don es el amor personal. El «don» manifiesta de manera dinámica la gratuidad del amor necesario a todo compromiso. El término no es restrictivo. A menudo acompañado de calificativos como «fiel, definitivo, mutuo, unitivo, total, recíproco, esponsal», ofrece una densidad de significados concretos y precisos. Para el Pueblo de Dios, este vocabulario es más comprensible que las palabras «fines» y «bienes». Lo experimentamos todos los días, la fe y la vida cristiana son una escuela del don.

Siendo feliz en su aplicación pastoral, la palabra «don» sumerge sus raíces en una reflexión metafísica, espiritual y teológica. Pues asistimos al surgimiento de este concepto en teología sacramental, donde no era muy utilizado. El desarrollo de esta temática permite la unificación de la vida cristiana y de las exigencias éticas del amor. La moral cristiana no es seguimiento de Cristo solo en su misterio pascual sino don de sí mismo hasta el final. Perder, «dar» su vida con Cristo para ganarla. La historia de todo amor es una historia de salvación, el don de persona a persona surge de Aquel que es Don en sí mismo y fuente de todo don. Como para Cristo, si hay «éxtasis» y comunión en el amor no es sino al precio de un «éxodo» de sí mismo. Darse a otro es encontrarse, encontrarse y encon-

16 René Habachi, filósofo libanés, nacido en Egipto en 1914. Fue amigo de Emmanuel Mounier, de Maurice Zundel y de Teilhard de Chardin. Fue director del departamento de filosofía de la Unesco en París, también tuvo una dilatada trayectoria docente y compartió sus actividades entre la escritura y las conferencias hasta su muerte en enero de 2003 [N. del T.]. 
trar a Cristo. Tal es la lógica del amor. El amor es la persona que se da. El amor es un don personal.

Lo hemos constatado en los documentos magisteriales, la terminología del don está ahora presente en la teología moral y sacramental. Por lo tanto, la teología moral puede tomar en cuenta, más expresamente, la historia de nuestras falencias, de nuestros errores, de nuestros pecados. ¿No es acaso el telón de fondo de todas las actuales cuestiones morales? La negatividad de la historia humana puede ser así asumida y transfigurada en el don y la bondad original de ser. Ella pone a la vez a todo ser humano en un universo donde el poder de la resurrección de Cristo inscribe su obra de reconciliación en nuestras pobrezas y rechazos. El amor burlado, el amor roto, el amor rechazado, el amor que se revela ya no está en el punto muerto de las prohibiciones ni obligaciones; está aclarado por la ternura de una gratuidad y de una abundancia de ser que da y perdona sin tregua. Las categorías clásicas de la teología moral fundamental pueden ser «revisitadas» a la luz del don. El hombre es un ser perdonado, es decir, siempre re-donado a sí mismo; dibuja en el don del perdón la forma de su existencia y su capacidad siempre renovada de poder hacer el bien sea cuales sean sus historias, sus heridas, sus miedos, sus pecados. El desafío pastoral de esta opción de teología moral no puede ser ignorado por aquellos que tratan los temas morales del matrimonio.

Entendemos que esta doctrina de «dones del matrimonio» está ligada a cuestiones fundamentales sobre el ser, la persona y la libertad. La teología del don renueva la visión del amor humano y su expresión sacramental en el matrimonio. La instrumentalización de los «fines» del matrimonio nos parece conjurada. El conjunto de las propiedades clásicas (unidad, indisolubilidad) está unificado en un nuevo lenguaje, que incluye al hombre y a la mujer como sujetos libres y personales, llamados a entregarse. El hijo es reconocido en la medida que lo que él es.

Liberar una lógica de gratuidad en la relación hombre-mujer, manifestar el don en la conyugalidad, reflexionar la originalidad del «misterio familiar» no es arqueología humana sino que es preparar la reflexión ulterior donde las diversas esferas de la vida social se fortalecen unas a otras en el respeto de las personas, en su mutuo reconocimiento. La teología del don y del perdón es fecunda y puede inspirar sin ninguna duda otras búsquedas.

\section{REFERENCIAS}

-Crespy, G., Evdokimov, P. \& Duquoc, C. (1966). Le mariage. Paris: Mame. -Folscheid, D. (1991). L'Esprit de l'athéisme et son destin. Paris: Ed. Universitaires. 
-Hennaux, J. M. (1989). Avant-Propos de A. Mattheeuws, Union et procréation. Développements de la doctrine des fins du mariage. Paris: Cerf.

-Juan Pablo II (1989). Discours aux participants au VIIe symposium des Évêques d'Europe sur le thème: Les attitudes contemporaines devant la naissance et la mort: un défi pour l'évangélisation (17 octobre). Documentation Catholique.

-Martelet, G. (1969). Existence humaine et amour. Paris: Desclée de Brouwer.

-Mattheeuws, A. (1989). Union et procréation. Développements de la doctrine des fins du mariage. Paris: Cerf.

-Mattheeuws, A. (1996). Les 'dons' du mariage. Recherche de théologie morale et sacramentelle. Culture et Vérité.

-Pío XI (1930). Encíclica Casti connubi. Roma: Libreria Editrice Vaticana.

Sumario: Introducción; 1. Las sucesivas doctrinas; $1.1 \mathrm{La}$ doctrina agustiniana de los «bienes» del matrimonio; 1.2 La doctrina tomista de los «fines»; 2. Integración de las doctrinas teológicas en el Magisterio; 2.1 Período preconciliar: dificultades y objeciones; 2.2 Perspectivas institucionales del matrimonio en un nuevo contexto; 2.3. Período conciliar; 2.4 Período postconciliar; 3. Nacimiento de la teología de los «dones»; 3.1. Eje cristológico y pneumatológico; 3.2. La instancia personalista; 3.3 Una espiritualidad conyugal; 4. ¿Una doctrina del «don»?; 4.1 Una «novedad doctrinal»; 4.2 Las ventajas de tal doctrina; 5. Integración de estas doctrinas; 6. La originalidad de este desarrollo; Referencias. 